\title{
SERUM TOTAL SIALIC ACID LEVELS AND SIALIC ACID ACETYL ESTERASE GENE VARIATION IN PATIENTS WITH PREECLAMPSIA
}

\author{
Ozlem GUL ${ }^{1}$, Ebru OZTURK ${ }^{1}$, Mete Gurol UGUR ${ }^{1}$, Fatma Bahar CEBESOY ${ }^{1}$, Naciye KURTUL ${ }^{2}$, Sadrettin PENCE ${ }^{3}$, \\ Sacide PEHLIVAN ${ }^{4}$, Ozcan BALAT ${ }^{1}$
}

\footnotetext{
${ }^{1}$ Department of Gynecology and Obstetric, Gaziantep University, Faculty of Medicine, Gaziantep, Turkey

2 Departmen of Chemistry, Kahramanmaras Sutcu Imam University, Faculty of Medicine, Kahramanmaras, Turkey

${ }^{3}$ Department of Physiology, Gaziantep University, Faculty of Medicine, Gaziantep, Turkey

${ }^{4}$ Department of Medical Biology and Genetics, Faculty of Medicine, Gaziantep, Turkey
}

\section{SUMMARY}

Objective: To evaluate the role of serum total sialic acid (SA) levels and sialic acid acetyl esterase (SIAE) gene variation in etiopathogenesis of preeclampsia $(P E)$.

Design: Prospective study

Setting: Gaziantep Üniversity, Medical School, Department of Obstetrics and Gynecology

Patients: This study was performed with 57 preeclamptic pregnant women and 50 pregnant women having no medical problems who has admitted to the Department of Obstetrics and Gynecology of Gaziantep University Medical Faculty between January 2008 and June 2008

Main outcome measures: Serum total SA levels were measured by Denny's colorimetric method and analysis of SIAE gene variation was performed by polymerase chain reaction -single stranded conformational polymorphism (PCR-SSCP). Statistical analyses were achieved using the SPSS 13.0 software. P<0.05 was considered to be statistically significant.

Results: In this study, we observed higher serum total SA levels in PE $(p<0.00001)$ and increased PE risk 10.4 times by SIAE gene variation. There was a weak-intermediate correlation between serum SA levels and diastolic blood pressure, uric acid levels ( $p=0.0001, r=0.34 ; p=0.0001, r=0.37$ respectively). There was a strong correlation between serum SA levels and proteinuria $(p=0.001, r=0.5)$. There was a significant association between SIAE gene variation and proteinuria $(393 \pm 238 \mathrm{vs} 107 \pm 185 \mathrm{mg} \mid \mathrm{L}, \mathrm{p}=0.021)$, diastolic blood pressure (102.7 $\pm 21.9 \mathrm{vs} 85.7 \pm 20.6 \mathrm{mmHg}$, $p=0.01)$.

Conclusions: Further studies to reveal the importance of measurement of serum total SA levels in early pregnancy or preconceptional analysis of SIAE gene variation for prediction of PE are needed

Key words: preeclampsia, sialic acid, sialic acid acetyl esterase gene variation

Journal of Turkish Society of Obstetrics and Gynecology, (J Turk Soc Obstet Gynecol), 2012; Vol: 9 Issue: 2 Pages: 99- 105

Address for Correspondence: Özlem Gül. Gaziantep Üniversitesi Kadın Hastalıkları ve Doğum Anabilim Dalı, Şahinbey, Gaziantep, Türkiye Phone: + 90 (533) 3441702

e-mail: dr_ozlemgul@yahoo.com

Received: 04 September 2011, revised: 23 November 2011, accepted: 07 December 2011, online publication: 08 December 2011 


\section{PREEKLAMPTIK GEBELERDE SERUM TOTAL SIALIK ASIT SEVIYYELERI VE SİALIKK ASIT ESTERAZ GEN VARYASYONU}

\section{ÖZET}

Objektif: Preeklampsi (PE) etiyopatogenezinde serum sialik asit (SA) seviyesi ve sialik asit esteraz (SİAE) gen varyasyonunun yerinin ortaya konulmast.

Planlama: Prospektif.

Ortam: Gaziantep Üniversitesi, Tip Fakültesi, Kadın Hastalıkları ve Doğum Anabilim Dalı.

Hastalar: Çalışmaya Ocak-Haziaran 2008 tarihleri arasında kliniğimize başvuran, 28-40 hafta arast 57 preeklamptik gebe ile herhangi bir medikal problemi olmayan 50 sağllklı gebe dahil edimiștir.

Değerlendirme parametreleri: Serum total SA seviyesi Denny'nin kolorimetrik metodu kullanilarak değerlendirilmişstir. SİAE gen varyasyon analizi, ilgili genin promotor bölgesi için tarafimızdan dizayn edilen primerler kullanılarak polymerase chain reaction -single stranded conformational polymorphism (PCR-SSCP) yöntemi ile gerçekleştirilmiştir. Çalıșmada elde edilen veriler SPSS 13.0 programı kullanılarak \% 95'lik güven aralığında ve anlamlılık $p<0.05$ düzeyinde değerlendirilmiştir.

Sonuç: Bu çalışmada preeklamptik gebelerde serum total SA seviyesinin arttı̆̆ $(p<0.00001)$ ve SİAE gen varyasyonunun PE gelișme riskini 10.4 kat artırdı̆̆ saptanmıștır. Serum SA seviyesi ile diastolik kan basıncı ve ürik asit seviyeleri arasinda zaylf-orta derecede korelasyon ( $p=0.0001, r=0.34 ; p=0.0001, r=0.37$; strasiyla), proteinüri ile iyi derecede korelasyon izlenmişstir ( $p=0.001, r=0.5$ ). SİAE gen varyasyonu orant ile proteinüri $(393 \pm 238 \mathrm{vs} 107 \pm 185 \mathrm{mg} \mid \mathrm{L}, \mathrm{p}=$ $0.021)$ ve diastolik kan basincı (102.7 21.9 vs $85.7 \pm 20.6 \mathrm{mmHg}, p=0.01)$ arasında anlaml ölçüde korelasyon saptanmıştır. Yorum: Preeklampsinin erken gebelik haftalarında prediksiyonunda serum total SA seviyelerinin önemini ortaya koymak, prekonsepsiyonel dönemde genetik analiz yapılarak PE gelișebilecek hastaların belirlenip belirlenemeyeceğini değerlendirmek için yeni genişserili prospektif çalışmalara ihtiyaç vardır.

Anahtar kelimeler: preeklampsi, sialik asit, sialik asit esteraz gen varyasyonu

Türk Jinekoloji ve Obstetrik Derneği Dergisi, (J Turk Soc Obstet Gynecol), 2012; Cilt: 9 Sayl: 2 Sayfa: 99- 105

\section{INTRODUCTION}

Pre-eclampsia is defined as hypertension and proteinuria, which is commonly observed in nullipares after 20th gestational week ${ }^{(1)}$. It is one of the important causes of fetomaternal morbidity and mortality, which includes a broad spectrum varying from $\mathrm{PE}$ and minimal increases of blood pressures to severe organ dysfunctions ${ }^{(2)}$.

Although abnormal trophoblast invasion of the uterine blood vessels, vascular endothelial dysfunction, incompatibility with inflammatory and cardiovascular changes occurring during the pregnancy and various genetic predispositions are believed to account for the etiopathogenesis of PE, this has not been fully elucidated yet ${ }^{(3)}$.

It is known that preeclampsia is characterized by an excessive increase of maternal inflammatory response and the factors that trigger the inflammatory response (infections and rheumatoid diseases) increased the likelihood of PE occurrence ${ }^{(4,5)}$. In the etiopathogenesis of the cardiovascular diseases (CVD), inflammatory cell activation is accounted for the occurrence of endothelial dysfunction, thrombotic and metabolic disorders. Increased risk for future CVD in the preeclamptic pregnant women and the fact that atherosclerosis and obesity are common risk factors for PE and CVD support the important role of inflammatory cell activation in the etiopathogenesis of $\mathrm{PE}^{(6,7)}$.

Sialic acid (SA) is a general name given to acetylated derivatives of the neuraminic acid ${ }^{(8)}$. Main role of the $\mathrm{SA}$ is to ensure the interaction between the cells and the infectious agents by regulating the molecular relations as well as structural and protective effects in the cell membrane ${ }^{(9)}$. Increased serum level of total SA was documented in various inflammatory diseases (10). There was a correlation between serum total SA level and acute phase proteins activated during the inflammation ${ }^{(11)}$. As a result, SA may be considered 
as an inflammatory marker, an adhesion molecule activated as a result of endothelial dysfunction and a cardiovascular risk factor in the ethiopathogenesis of PE.

Majority of the sialic acids are converted to 0 -acetyl esters, which are involved in cell adhesion, lectin recognition, tissue modeling and various biological events (tumor antigenity, binding of virus, complement activation), with the effect of sialic acid esterase (SIAE) enzyme. SIAE enzyme, which has lysosomal and cytosolic isoforms, is encoded by SIAE gene located on chromosome 11q24 that has been discovered in 2004(12,13).

It is known that there is a strong familial predisposition to preeclampsia. Although many candidate genes have been shown as a risk factor for the recent years, the literature does not contain a study that evaliated the correlation between SIAE gene variation and $\operatorname{PE}^{(14,15)}$. This study aimed to determine whether serum total SA level and sialic acid acetyl esterase (SIAE) gene variation could be used as a risk factor to priorly diagnose the preeclampsia and to determine its severity and to take precautions in the early prenatal period.

\section{MATERIAL AND METHODS}

We enrolled 57 preeclamptic pregnant women with a gestational age between 28 and 40 weeks and 50 healthy pregnant women without any medical problems, who were presented to the Department of Gynecological and Obstetric Diseases of Gaziantep University Medical Faculty between 08/01/2008 and 4/6/2008. The study was approved by Ethical Board of GAZU Medical Faculty (07/01/2008-decree no:01-2008\07).

Preeclampsia was diagnosed based on the observation of a blood pressure $\geq 140 / 90 \mathrm{mmHg}$ and urinary protein level $\geq 300 \mathrm{mg} / \mathrm{L}$ (at least +1 , using dipstick) during 2 measurements performed with at least 6-hour intervals. Severe PE criteria included blood pressure $\geq 160 / 110$, proteinuria $\geq 5 \mathrm{gr} / 24$ hours or $3+/ 4+$ on stick test, oliguria ( $\geq 500 \mathrm{ml} / 24$ hours), impaired vision, cerebral disorder, convulsion, headache, epigastric pain, nausea, vomiting, elevation of serum creatinine level, thrombocytopenia $(<100000)$, impairment of hepatic functions or peripheral smear, pulmonary edema and cyanosis, abnormal umbilical artery Doppler findings as well as intrauterine growth restriction or oligohydramniosis
$(16,17)$. Control group included the pregnant women without any medical problem, who had normal results of renal and hepatic function tests and blood pressure. For both groups, sociodemographic, reproductive, medical and laboratory data and ultrasound findings of the fetus were recorded in the patient monitorization forms. Exclusion criteria included multiple pregnancies, fetal anomaly, maternal infection or maternal systemic disease.

Each patient gave a total of $7 \mathrm{ml}$ peripheral blood, 5 $\mathrm{ml}$ being drawn in normal tube to evaluate serum total SA level and $2 \mathrm{ml}$ being drawn to EDTA tube for the detection of the polymorphism located in SIAE promoter domain. Blood samples drawn for the determination of serum SA level were centrifuged at $1600 \mathrm{~g} / \mathrm{min}$ for 15 minutes and the serum samples obtained were stored at $-80^{\circ} \mathrm{C}$ until the time of use. For the measurement of serum total SA level, Denny's colorimetric method was used ${ }^{(18)}$. This method is the modified version of Aminoff and Warren methods, which are thiobarbituric acid (TBA) colorimetric assays that are commonly used for the measurement of total SA level ${ }^{(19,20)}$. For the analysis of SIAE gene variation, DNAs were isolated from the peripheral blood samples obtained from patient and control groups using the precipitation method at high salt concentrations and were stored at $-20^{\circ} \mathrm{C}(21)$. SIAE gene was studied using the primers regulated in the program of wrokxx banch designed for promoter domain(13). The concerned domains were amplified using polymerase chain reaction (PCR) and thereafter, the amplifications of the samples were controlled using $2 \%$ agarose gel, the analysis of the differences of domains were conducted by performing Single stranded conformational polymorphism (SSCP) analysis using 7\% nondenaturated page and the visualization was done using staining with silver(22)

The results obtained from the study were evaluated within $95 \%$ confidence intervals and at a significance level of $\mathrm{p}<0.05$ using SPSS 13.0 (Statistical Package for Social Sciences) software. Continuous variables were compared using Independent T Test or MannWhitney U test between two groups, whereas ANOVA test was used when the number of groups was above two. Categorical variables were compared using chisqaure test and Fisher's exact test between the groups. Risk coefficients were calculated using odss ratio and 95\% confidence intervals were given. Correlation 
analysis of the variables was performed using Pearson correlation analysis.

\section{RESULTS}

For 57 pregnant women of PE groups (20 mild preeclampsia and 37 severe preeclampsia) and 50 pregnant women of the control group, demographic and clinical findings were given in Table I. Serum levels of sialic acid were statistically significantly elevated in PE group $(3.53 \pm 1.37 \mathrm{mmol} / \mathrm{l})$ compared to control group $(2.32 \pm 0.68 \mathrm{mmol} \backslash \mathrm{l})(\mathrm{p}<0.00001)$ (Table II).

Table I: Demographic and clinical findings of the patient and control groups.

\begin{tabular}{|c|c|c|c|}
\hline & $\begin{array}{l}\text { Patient group } \\
(n=57) \text { Mean } \pm \text { SS }\end{array}$ & $\begin{array}{l}\text { Control group } \\
(n=50) \text { Mean } \pm \text { SS }\end{array}$ & p \\
\hline Age (years) & $29.0 \pm 6.5$ & $30.2 \pm 5.3$ & NS \\
\hline Pregnancy week & $34.5 \pm 3.5$ & $35.0 \pm 2.5$ & NS \\
\hline $\mathrm{BMI}\left(\mathrm{kg} \backslash \mathrm{m}^{2}\right)$ & $28.9 \pm 3.5$ & $27.7 \pm 2.4$ & 0.04 \\
\hline Systolic BP (mmHg) & $157.1 \pm 21.2$ & $120.8 \pm 10.4$ & 0.0001 \\
\hline Diastolic BP (mmHg) & $100.9 \pm 14.8$ & $72.1 \pm 16.6$ & 0.0001 \\
\hline Hemoglobin (gr\dl) & $12.1 \pm 1.8$ & $11.8 \pm 1.2$ & NS \\
\hline White blood cells $\left(10^{3} / \mu \mathrm{l}\right)$ & $12,4 \pm 4,9$ & $10,5 \pm 3,0$ & 0.01 \\
\hline Thrombocyte $\left(10^{3} / \mu \mathrm{l}\right)$ & $192,6 \pm 94,3$ & $237,3 \pm 123,2$ & 0.03 \\
\hline ALT (U\L) & $74.4 \pm 246.9$ & $16.8 \pm 9.6$ & 0.0001 \\
\hline AST (U\L) & $52.4 \pm 84.4$ & $19 \pm 12.2$ & 0.0001 \\
\hline Urea (mg\dl) & $27.9 \pm 14$ & $17.2 \pm 5.3$ & 0.0001 \\
\hline Creatinine (mg/dl) & $0.7 \pm 0.34$ & $0.7 \pm 1.1$ & NS \\
\hline Uric acid (mg\dl) & $6.2 \pm 1.5$ & $2.7 \pm 1.5$ & 0.001 \\
\hline Proteinuria $(\mathrm{mg} \backslash \mathrm{L})$ & $336 \pm 210$ & 0 & 0.0001 \\
\hline
\end{tabular}

$B M I$, body mass index; BP, blood pressure; ALT, alanine aminotransferase; AST, aspartate aminotransferase; NS, not significant; SS, standart deviation.

Tablo II: Serum levels of sialic acid (SA) and sialic acid acetyl esterase (SIAE) gene variations in the patient and control groups.

\begin{tabular}{llll}
\hline & $\begin{array}{l}\text { Patient Group } \\
(\mathbf{n}=\mathbf{5 7})\end{array}$ & $\begin{array}{l}\text { Control Group } \\
(\mathbf{n}=\mathbf{5 0})\end{array}$ & \\
\hline $\begin{array}{l}\text { Serum levels of SA } \\
(\mathrm{mmol} \backslash \mathrm{lt})\end{array}$ & $3.53 \pm 1.37$ & $2.32 \pm 0.68$ & $<0.00001^{*}$ \\
$\begin{array}{l}\text { SIAE gene } \\
\text { variation }(+) /(-)\end{array}$ & $\begin{array}{l}10(\% 17.5) / 47 \\
(\% 82.5)\end{array}$ & $\begin{array}{l}1(\% 2) / 49 \\
(\% 98)\end{array}$ & $0.008^{* *}$ \\
& & & \\
\hline
\end{tabular}

*Independent $t$ test

**Chi-square, OR (Odds ratio): 10.4 (95\% CI; 1.2-84.6)

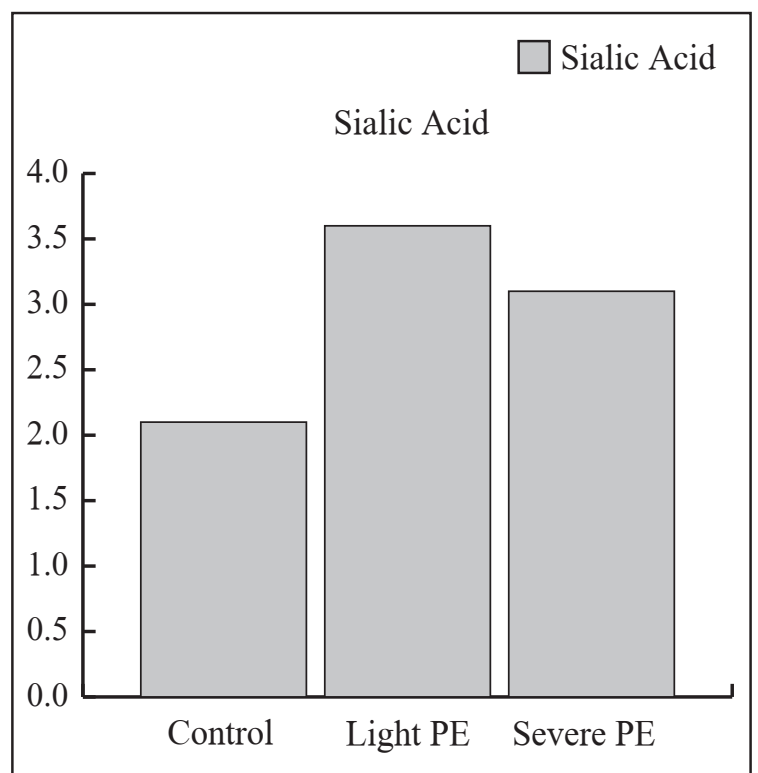

Figure 1: Serum levels of sialic acid in the groups of mild preeclampsia (PE), severe PE and control group.

Table III: Correlation analysis between serum level of sialic acid (SA) and age, body mass index (BMI), blood pressure (BP) and laboratory parameters.

\begin{tabular}{lll}
\hline & r (correlation coefficient) & P \\
\hline SA-BMI & 0.17 & 0.06 \\
SA-Age & -0.13 & 0.17 \\
SA-Systolic BP & 0.22 & 0.02 \\
SA-Diastolic BP & 0.34 & $\mathbf{0 . 0 0 0 1}$ \\
SA-ALT & 0.01 & 0.86 \\
SA-AST & 0.15 & 0.11 \\
SA-Urea & 0.10 & 0.29 \\
SA-Creatinine & 0.02 & 0.76 \\
SA-White blood cell & 0.007 & 0.89 \\
SA-Thrombocyte & -0.05 & 0.57 \\
SA-Hemoglobin & 0.08 & 0.38 \\
SA-Proteinuria & 0.5 & $\mathbf{0 . 0 0 1}$ \\
SA-Uric acid & 0.379 & $\mathbf{0 . 0 0 0 1}$ \\
\hline
\end{tabular}

When the patient group was divided into two subgroups called mild and severe PE, serum levels of sialic acid was significantly elevated in both mild and severe PE groups $(3.8 \pm 0.9,3.3 \pm 1.5 \mathrm{mmol} \backslash 1$, respectively) compared to control group $(2.3 \pm 0.7 \mathrm{mmol} \backslash \mathrm{l})(\mathrm{p}<0.001$, $\mathrm{p}<0.001$ ), but no significant difference was found between mild and severe PE groups $(\mathrm{p}=0.22)$ (Figure $1)$.

Serum levels of SA showed a mild-moderate correlation with diastolic blood pressure and the levels of uric acid ( $p=0.0001, r=0.34 ; p=0.0001, r=0.37$, respectively) and a strong correlation with proteinuria $(\mathrm{p}=0.001$, $\mathrm{r}=0.5)$ (Table III). 


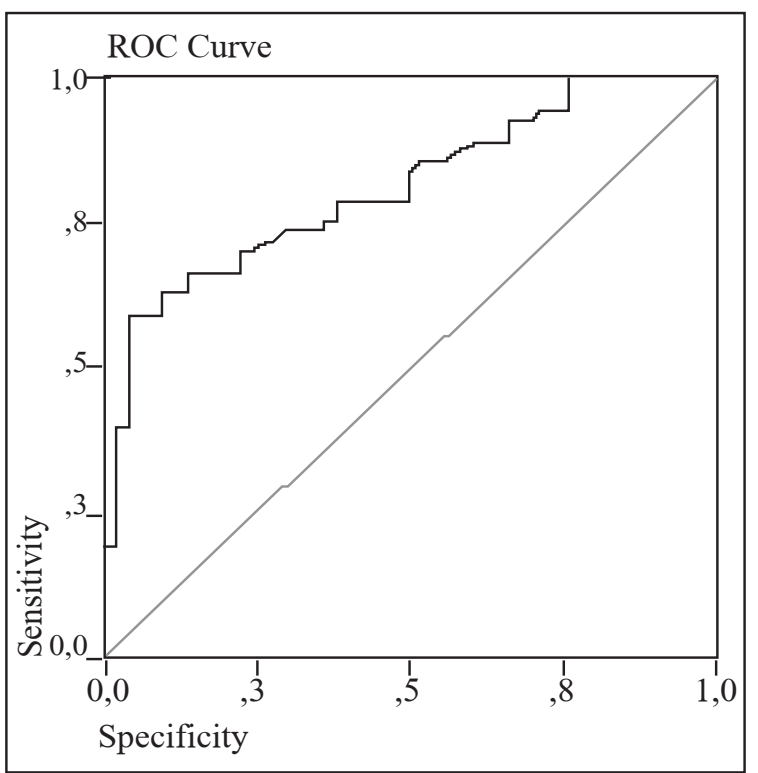

Figure 2: ROC curve between serum level of sialic acid and preeclampsia.

Table IV: Correlation between SIAE gene variation and serum level of $S A$, body mass index (BMI), blood pressure (BP) and laboratory parameters.

\begin{tabular}{llll}
\hline & $\begin{array}{l}\text { SIAE gene } \\
\text { variation } \\
(+)(n=11)\end{array}$ & $\begin{array}{l}\text { SIAE gene } \\
\text { variation } \\
(-))(n=96)\end{array}$ & P \\
\hline Sialic acid & $3.3+0.7$ & $2.9+1.3$ & 0.35 \\
Thrombocyte & $202363+122256$ & $214760+109721$ & 0.72 \\
BMI & $27.6+1.8$ & $27.6+2.3$ & 0.96 \\
Systolic BP & $153.2+25.8$ & $138.6+28.5$ & 0.06 \\
Diastolic BP & $102.7+21.9$ & $85.7+20.6$ & 0.01 \\
ALT* & $204.3+555.9$ & $29.5+34.6$ & 0.25 \\
AST* & $99.4+171.7$ & $29.6+31.3$ & 0.10 \\
Hemoglobin & $12.7+1.4$ & $11.9+1.6$ & 0.13 \\
Urea* & $28.8+19.7$ & $22.2+10.8$ & 0.36 \\
Creatinine* & $0.6+0.3$ & $0.7+0.8$ & 0.90 \\
White blood cell & $11811+2794$ & $11494+4418$ & 0.81 \\
Proteinuria & $393 \pm 238$ & $107 \pm 185$ & 0.021 \\
Uric acid & $5.2 \pm 1.6$ & $4.5 \pm 2.4$ & 0.22 \\
\hline
\end{tabular}

*Mann Whitney U test was used. Others were tested using Independent T test $(p<0.05$ was considered as statistically significant).

To diagnose PE based on the serum level of SA, "Receiver-operating characteristic" (ROC) analysis was used. Area under the ROC curve between preeclampsia and sialic acid was evaluated to be 0.811 (CI \%95; 0.731-0.892, $\mathrm{p}<0.001$ ) (Figure 2). In the preeclampsia, when the level of sialic acid was considered as $2.31 \mathrm{mmol} / \mathrm{l}$, the sensitivity was $80 \%$, specificity was $50 \%$, positive predictor value was $61 \%$ and negative predictive value was $30 \%$.
Preeclamptic pregnant women showed a significantly higher gene variation compared to those of control group and the likelihood of gene variation was 10.4 times more common in preeclamptic pregnant women compared to those of control group (Table II). When PE group was divided into subgroups, SIAE gene variation rate was significantly higher in severe PE group (p:0.001; OR: 15.7, \%95 CI; 1.8-130.8) and was higher with a borderline significance in the mild PE group (p:0.06 OR: 6.1 (\%95 CI; 0.7- 52.2).

A significant correlation was found between SIAE gene variation rate and proteinuria $(393 \pm 238$ vs. $107 \pm 185 \mathrm{mg} \backslash \mathrm{L}, \mathrm{p}=0.021)$ and diastolic blood pressure (102.7 \pm 21.9 vs. $85.7 \pm 20.6 \mathrm{mmHg}, \mathrm{p}=0.01)$ (Table IV).

\section{DISCUSSION}

Despite many actual studies, the etiopathogenesis of the preeclampsia has not been fully understood.

It is known that the inflammatory condition observed in the normal pregnancy modifies and increases with the activation of neutrophiles in $\mathrm{PE}^{(23,24)}$. The studies that have been conducted for the last years suggested that the sialic acid that has been demonstrated to be correlated with acute phase reactants could play a role in the etiopathogenesis of the PE. However, in the literature, the studies that evaluated SA in the preeclamptic pregnant women were very limited.

In the literature, the only study that evaluated serum levels of SA in the preeclamptic pregnant women was the study conducted by von Versen-Hoeynck FM et al., which evaluated the levels of SA and CRP in five different groups, as non-pregnant women, healthy pregnant women, preeclamptic pregnant women, the pregnant women who showed SGA without preeclampsia and the pregnant women who showed temporary hypertension ${ }^{(25)}$. In this study, the levels of SA were found to be correlated with CRP and neopterine, but the level of neopterine was statistically significantly higher in the preeclamptic pregnant women, whereas this difference could not be demonstrated for the levels of SA and CRP. In our study, unlike the study conducted by von VersenHoeynck FM et al., serum levels of SA were found to be statistically significantly higher in the PE group compared to control group. The difference between two studies could have resulted from the measuring 
method used to measure SA. In the study performed by von Versen-Hoeynck FM et al., it was stated that the level of SA was measured using diagnostic kit, but no detailed information was given about the measurement method, i.e., it was not stated whether total or free SA was measured. In our study, serum total SA measurement was performed using Denny's colorimetric method. This study has been the first study present in the English literature that revealed the importance of serum level of total SA in the prediction of PE. In this study, serum levels of total SA showed a significant correlation with diastolic blood pressure, proteinuria and serum levels of uric acid.

The studies that have been conducted for the last years demonstrated that SA contained about 10 humanspecific genetic variations(26). Again, this studies demonstrated the correlation between human autoimmune diseases and genetic variants of the sialic acid acetylesterase enzyme (SIAE), which consisted the most commonly seen modification of SAs present on the cell surface of the mammalians ${ }^{(27)}$. In our study, SIAE gene variations were evaluated in the PE, which was human-specific pathology and for which autoimmune mechanisms were thought to play a role in the physiopathology, the rate of gene variation was found to be significantly higher in the preeclamptic patients compared to control group, and the likelihood of gene variation in the preeclamptic pregnant women was found to be 10.4 fold higher compared to controls. This result was consistent with those of the study performed by Tsai et al.(28). Tsai et al. detected a dysregulation of SIAE gene transcription in the placenta of the preeclamptic pregnant women. Again, Winn VD et al. (29) showed the correlation between Sialic Acid-Binding Immunoglobulin-LikeLectin-6 gene expression and severe PE and stated that serum levels of these proteins could be used for the diagnosis or the prediction of PE. Our study has been the first study in the literature to evaluate the role of serum levels of total SA in the prediction of PE and to concomitantly demonstrate that SIAE gene variation was a risk factor for PE.

Consequently, in this study, it was determined that, in preeclamptic pregnant women, increased serum levels of total SA and SIAE gene variation increased the risk for PE occurrence by 10.4 fold. New prospective studies with large series of patients are warranted to reveal the importance of serum levels of total SA in the prediction of PE in the early gestational weeks and to evaluate whether the patients with the potential of preeclampsia development could be determined by performing a genetic analysis in the preconceptional period.

\section{REFERENCES}

1. Cunningham FG, Leveno JK, Bloom LS. Williams Obstetrics. 2005; 22:m761- 70 .

2. Atrash HK, Konin LM, Lawson HW, Franks AL, Smith JC. Maternal mortality in the United States, 1979-1986. Obstet Gyneacol 1990; 76: 1055- 60 .

3. Dekker GA, Sibai BM. Pathogenesis and etiology of preeclampsia. Am J Obstet Gynecol 1998; 179: 1359.

4. Sibai B. Preeclampsia: An inflammatory syndrome? Am J Obstet Gynecol 2004; 191: 1061- 2.

5. Borzychowski AM, Sargent IL, Redman CWG. Inflammation and pre-eclampsia. Seminars in fetal and neonatal medicine. 2006; 11: 309- 16

6. Dilys JF, Frances McManus, Elizabeth AB. Short and Long Term Changes in Plasma Inflammatory Markers Associted With Preeclampsia. Hypertension 2004; 44: 708- 14.

7. Vita JA, Brennan ML, Gokce N, Mann SA, Goormastic M, Shishehbor $\mathrm{MH}$ et al. Serum myeloperoxidase levels independently predict endothelial dysfunction in humans. Circulation 2004; 110: 1134- 9.

8. Schauer R, Kelm S, Reuter G, Roggentin P, Shaw L. Biochemistry and role of sialic acids. In: Rosenberg A, (ed). Biology of the Sialic Acids. New York: Plenum. 1995: 2- 9.

9. Schauer R. Achievements and challenges of sialic acid research. Glycoconj J 2000; 17: 485- 99.

10. Sillanaukee P, Ponnio M, Jaaskelainen IP. Occurrence of sialic acids in healthy humans and different disorders. Eur J Clin Invest 1999; 29: 413- 25.

11. Taniuchi K, Chifu K, Hayashi N. A new enzymatic method for the determination of sialic acid in serum and its application for a marker of acute phase reactants. Kobe JMed Sci 1981; 27: $91-102$.

12. Takematsu, H, Diaz S, Stoddar A, Zang Y, Varki A. Lysosomal and cytosolic sialic acid 9-O-acetylesterase activities can be encoded by one gene via differential usage of a signal peptideencoding exon at the $\mathrm{N}$ terminus. J Biol Chem. 1999; 274: 25623- 31 .

13. Zhu H, Chan HC, Zhou Z, Li J, Zhu H, Yin L et al. A gene encoding sialic-acid-specific 9-O-acetylesterase found in human testis. J Biomed Biotech. 2004; 3: 130- 6. 
14. Augusta M A, Lachmeijer AB, Guustaaf A, Dekker C, Gerard P, Jan G et al. Searching for preeclampsia genes: The current position. Eur J Obstet \& Gynecol Reprod Biol 2002; 105: 94 113.

15. Broughton PF. What is the place of genetics in the pathogenesis of pre-eclampsia? Biol Neonate 1999; 76: 325- 30.

16. American College of Obstetriceans and Gynecologists. Committee on Technical Bulletins. Hypertension in pregnancy. ACOG Technical bulletin. 1996; 219: 1- 8 .

17. National high blood pressure education program working group. Report on high blood pressure in pregnancy. Am J Obstet Gynecol. 1990; 163: 1691- 712.

18. Suzuki K. Sialic acid in biochemical pathology. In: Rosenberg, A ed. Biology of the sialic acids. New York: Plenum. 1995: 10- 37

19. Aminoff D. Methods for the quantitative estimation of $\mathrm{N}$ acetylneuraminic acid and their application to hydrolysates of sialomucoids. Biochem J 1961; 81: 384- 92.

20. Warren L. The thiobarbituric acid assay of sialic acids. J Biol Chem 1959; 234: 1971- 5

21. Miller SA, Dykes DD, Polesky HF: A simple salting out procedure for extracting DNA from human nucleated cells. Nucleic Acids Res 1988; 16: 1215.

22. Pehlivan S, Koyuncuoğlu M, Pehlivan M, Izzetoğlu S, Mater Y, Çabuk M, Kirkali Z. Premalignant lesions of the kidney share the same genetics changes as conventional renal cell carcinoma. World J Urol 2004; 22: 120- 3.
23. Redman CW, Sacks GP, Sargent IL. Preeclampsia: an excessive maternal inflammatory response to pregnancy. Am J Obstet Gynecol 1999; 180: 499- 506.

24. Bretelle F, Sabatier F, Shojai R, Agostini A, Dignat-George F, Blanc B et al. New insight in physiopathology of preeclampsia and intra-uterine growth retardation: role of inflammation. Gynecol Obstet Fertil 2004; 32: 482- 9.

25. von Versen-Hoeynck FM, Hubel CA, Gallaher MJ, Gammill HS, Powers RW. Plasma levels of inflammatory markers neopterin, sialic acid, and C-reactive protein in pregnancy and preeclampsia. Am J Hypertens 2009; 22: 687- 92.

26. Varki A. Colloquium paper: uniquely human evolution of sialic acid genetics and biology. Proc Natl Acad Sci USA 2010; 107: 8939- 46.

27. Surolia I, Pirnie SP, Chellappa V, Taylor KN, Cariappa A, Moya $\mathrm{J}$ et al. Functionally defective germline variants of sialic acid acetylesterase in autoimmunity. Nature 2010; 466: 243- 7.

28. Tsai S, Hardison NE, James AH, Motsinger-Reif AA, Bischoff SR, Thames BH, Piedrahita JA. Transcriptional profiling of human placentas from pregnancies complicated by preeclampsia reveals disregulation of sialic acid acetylesterase and immune signalling pathways. Placenta 2011; 32: 175- 82 .

29. Winn VD, Gormley M, Paquet AC, Kjaer-Sorensen K, Kramer A, Rumer KK, et al. Severe preeclampsia-related changes in gene expression at the maternal-fetal interface include sialic acid-binding immunoglobulin-like lectin-6 and pappalysin2. Endocrinology 2009; 150: 452- 62. 